\title{
Incidence of the Rice Root-Knot Nematode, Meloidogyne graminicola, in Guangxi, China
}

\author{
Man Luo, Bing Xue Li, and Han Yan Wu (iD * \\ Guangxi Key Laboratory of Agric-Environment and Agric-Products Safety, Agricultural College of Guangxi University, \\ Nanning 530004, China
}

(Received on November 14, 2019; Revised on February 9, 2020; Accepted on March 6, 2020)

Root-knot nematodes (Meloidogyne spp.) are the most destructive group of plant-parasitic nematodes. Plants infected by Meloidogyne spp. develop above-ground symptoms, stunting, yellowing, nutrient deficiencies, and gall formations with typical hook-shaped root tips. Infected plants experience yield losses. During 20182019 survey, leaf chlorosis rice plants were found in 206 fields of 67 counties in Guangxi, China, around 30 days after transplanting. Galls and hooked tips on the roots and pear-shaped females were observed. About 32.04\% of fields were infested with the nematode. The nematodes were identified as Meloidogyne graminicola base on morphological and molecular analysis. To the best of our knowledge, this is the first report of M. graminicola on rice plants in Guangxi, China. The results of this study urge the discovery of resistant cultivars and the development of management strategies.

Keywords : incidence, Meloidogyne graminicola, rice

Handling Editor : Dong-Geun Kim

Root-knot nematode (Meloidogyne spp.; RKN), the sedentary endoparasitic nematode, is one of the most eco-

\footnotetext{
*Corresponding author.

Phone/FAX) +86-771-3235612

E-mail)whyzxb@gmail.com

ORCID

Han Yan $\mathrm{Wu}$

https://orcid.org/0000-0001-5322-3425

(c) This is an Open Access article distributed under the terms of the Creative Commons Attribution Non-Commercial License (http:// creativecommons.org/licenses/by-nc/4.0) which permits unrestricted noncommercial use, distribution, and reproduction in any medium, provided the original work is properly cited.
}

Articles can be freely viewed online at www.ppjonline.org. nomically significant plant-parasitic nematodes, more than 100 species were recognized in this genus (Janati et al., 2018). Symptoms associated with RKN infection can be easily diagnosed by farmers by the distinctive galls. Plants infected by RKN show symptoms such as; yellow leaves, stunted growth, nutrient deficiencies, and secondary infections by other pathogens (Hunt and Handoo, 2009; Mantelin et al., 2017). Approximately 29 species of nematodes have been described in association with losses in irrigated rice. Among of them, Paratrichodorus minor, Aphelenchoides besseyi, Ditylenchus angustus, Heterodera elachista, Hirschmanniella oryzae, Meloidogyne incognita, M. javanica, $M$. arenaria, and $M$. oryzae have significant detrimental effects (Mantelin et al., 2017; Negretti et al., 2017). Meloidogyne graminicola, one of the major species in RKN, was first isolated from the roots of barnyard grass (Echinochloa colonum L.) in Baton Rouge, LA, USA, and was reported by Golden and Birchfield (1965). Subsequently, this nematode was identified in many countries. The nematode has a wide range of alternative hosts; cereals, dicotyledonous, grass plants, and rice, the most important host (Bridge et al., 2005; Rich et al., 2009). $M$. graminicola is the most prevalent plant-parasitic nematode on rice and is considered a major threat to rice. This nematode cause $16-20 \%$ loss in lowland rainfed rice in Bangladesh, and cause $16-32 \%$ yield losses under irrigated and $11-73 \%$ under flooded conditions in India, respectively (Tian et al., 2018).

In China, M. graminicola was first discovered on Allium tistulosum in the Hainan province (Zhao et al., 2001). The nematode was then discovered on rice in China in Fujian, Hunan, Hubei, Zhejiang, Jiangxi and Sichuan Province (Song et al., 2017; Xie et al., 2019). Incidence of the disease is severe in the Hunan provinces, China. Disease incidence exceeded $85 \%$ in infected paddy fields (Song et al., 2017). In Guangxi, a survey of the RKN disease 
Table 1. Occurrence and detection of Meloidogyne graminicola on rice in Guangxi, China

\begin{tabular}{|c|c|c|c|c|c|c|}
\hline \multirow{2}{*}{ City } & \multirow{2}{*}{ County } & \multirow{2}{*}{ Latitude } & \multirow{2}{*}{ Longitude } & \multicolumn{3}{|c|}{ Sequences } \\
\hline & & & & ITS & D2-D3 & ITS1-5.8S-ITS2 \\
\hline \multirow[t]{3}{*}{ Nanning } & Binyang & $23^{\circ} 10^{\prime} 23^{\prime \prime}$ & $109^{\circ} 00^{\prime} 33^{\prime \prime}$ & MN519726 & MN513028 & MN049602 \\
\hline & Heng & $22^{\circ} 52^{\prime} 29^{\prime \prime}$ & $108^{\circ} 53^{\prime} 19^{\prime \prime}$ & MN128225 & MN513029 & MN647543 \\
\hline & Wuming & $23^{\circ} 02^{\prime} 18^{\prime \prime}$ & $108^{\circ} 19^{\prime} 48^{\prime \prime}$ & MN511736 & MN647592 & MN513027 \\
\hline \multirow[t]{4}{*}{ Laibin } & Xingbin & $23^{\circ} 24^{\prime} 13^{\prime \prime}$ & $109^{\circ} 07^{\prime} 38^{\prime \prime}$ & MN521459 & MN647590 & MN647593 \\
\hline & Jinxiu & $24^{\circ} 23^{\prime} 34^{\prime \prime}$ & $110^{\circ} 07^{\prime} 31^{\prime \prime}$ & $-^{a}$ & $-^{a}$ & $-^{a}$ \\
\hline & Wuxuan & $23^{\circ} 21^{\prime} 59^{\prime \prime}$ & $109^{\circ} 32^{\prime} 41^{\prime \prime}$ & $-^{a}$ & $-^{\mathrm{a}}$ & $--^{a}$ \\
\hline & Xiangzhou & $23^{\circ} 53^{\prime} 34^{\prime \prime}$ & $109^{\circ} 33^{\prime} 13^{\prime \prime}$ & $-{ }^{a}$ & $-^{\mathrm{a}}$ & $-^{\mathrm{a}}$ \\
\hline Liuzhou & Rong'an & $25^{\circ} 10^{\prime} 58^{\prime \prime}$ & $109^{\circ} 23^{\prime} 31^{\prime \prime}$ & $-{ }^{a}$ & $-^{\mathrm{a}}$ & $--^{a}$ \\
\hline \multirow[t]{2}{*}{ Guilin } & Yongfu & $25^{\circ} 05^{\prime} 44^{\prime \prime}$ & $110^{\circ} 03^{\prime} 19^{\prime \prime}$ & $-^{a}$ & $-^{\mathrm{a}}$ & $-^{a}$ \\
\hline & Quanzhou & $26^{\circ} 05^{\prime} 41^{\prime \prime}$ & $111^{\circ} 14^{\prime} 32^{\prime \prime}$ & $-^{\mathrm{a}}$ & $-^{\mathrm{a}}$ & $--^{a}$ \\
\hline \multirow[t]{2}{*}{ Hechi } & Nandan & $25^{\circ} 01^{\prime} 15^{\prime \prime}$ & $107^{\circ} 33^{\prime} 35^{\prime \prime}$ & $-^{a}$ & $-^{\mathrm{a}}$ & $-^{\mathrm{a}}$ \\
\hline & Dahua & $23^{\circ} 42^{\prime} 47^{\prime \prime}$ & $108^{\circ} 00^{\prime} 54^{\prime \prime}$ & $-{ }^{a}$ & $-^{a}$ & $-^{\mathrm{a}}$ \\
\hline Chongzuo & Ningming & $22^{\circ} 07^{\prime} 05^{\prime \prime}$ & $106^{\circ} 57^{\prime} 40^{\prime \prime}$ & $-{ }^{a}$ & $-^{\mathrm{a}}$ & $-{ }^{a}$ \\
\hline Hezhou & Pinggui & $24^{\circ} 21^{\prime} 34^{\prime \prime}$ & $111^{\circ} 28^{\prime} 30^{\prime \prime}$ & $-{ }^{\mathrm{a}}$ & $-^{\mathrm{a}}$ & $-^{\mathrm{a}}$ \\
\hline \multirow[t]{2}{*}{ Wuzhou } & Cangwu & $23^{\circ} 49^{\prime} 49^{\prime \prime}$ & $111^{\circ} 32^{\prime} 24^{\prime \prime}$ & $-{ }^{\mathrm{a}}$ & $-^{\mathrm{a}}$ & $-^{\mathrm{a}}$ \\
\hline & Cenxi & $22^{\circ} 55^{\prime} 02^{\prime \prime}$ & $110^{\circ} 53^{\prime} 28^{\prime \prime}$ & $-{ }^{a}$ & $-^{\mathrm{a}}$ & $--^{a}$ \\
\hline \multirow[t]{2}{*}{ Guigang } & Guiping & $23^{\circ} 27^{\prime} 30^{\prime \prime}$ & $110^{\circ} 09^{\prime} 48^{\prime \prime}$ & $-^{a}$ & $-^{\mathrm{a}}$ & $--^{a}$ \\
\hline & Qintang & $23^{\circ} 02^{\prime} 41^{\prime \prime}$ & $109^{\circ} 23^{\prime} 33^{\prime \prime}$ & $-^{\mathrm{a}}$ & $-^{\mathrm{a}}$ & $-{ }^{\mathrm{a}}$ \\
\hline Qinzhou & Lingshan & $22^{\circ} 15^{\prime} 54^{\prime \prime}$ & $108^{\circ} 59^{\prime} 47^{\prime \prime}$ & $-{ }^{a}$ & $-^{\mathrm{a}}$ & $--^{a}$ \\
\hline Beihai & Hepu & $21^{\circ} 39^{\prime} 59^{\prime \prime}$ & $109^{\circ} 10^{\prime} 21^{\prime \prime}$ & $-{ }^{\mathrm{a}}$ & $--^{\mathrm{a}}$ & $--^{\mathrm{a}}$ \\
\hline Fangchenggang & Shangsi & $22^{\circ} 10^{\prime} 23^{\prime \prime}$ & $107^{\circ} 59^{\prime} 56^{\prime \prime}$ & $-{ }^{a}$ & $-^{\mathrm{a}}$ & $--^{a}$ \\
\hline \multirow[t]{5}{*}{ Yulin } & Bobai & $22^{\circ} 12^{\prime} 30^{\prime \prime}$ & $109^{\circ} 58^{\prime} 48^{\prime \prime}$ & $-{ }^{a}$ & $-^{a}$ & $-^{\mathrm{a}}$ \\
\hline & Luchuan & $22^{\circ} 27^{\prime} 07^{\prime \prime}$ & $110^{\circ} 14^{\prime} 03^{\prime \prime}$ & $-{ }^{a}$ & $-^{\mathrm{a}}$ & $-{ }^{a}$ \\
\hline & Rong & $22^{\circ} 55^{\prime} 34^{\prime \prime}$ & $110^{\circ} 29^{\prime} 37^{\prime \prime}$ & $-^{\mathrm{a}}$ & $-^{\mathrm{a}}$ & $-{ }^{\mathrm{a}}$ \\
\hline & Xingye & $22^{\circ} 49^{\prime} 12^{\prime \prime}$ & $109^{\circ} 51^{\prime} 41^{\prime \prime}$ & $-^{a}$ & $-^{a}$ & $-^{\mathrm{a}}$ \\
\hline & Beiliu & $22^{\circ} 35^{\prime} 03^{\prime \prime}$ & $110^{\circ} 16^{\prime} 57^{\prime \prime}$ & $-^{a}$ & $-^{\mathrm{a}}$ & $-^{\mathrm{a}}$ \\
\hline
\end{tabular}

ITS, internal transcribed spacer.

${ }^{a}$ The sequence was not deposited to the GenBank because they have the same sequences as the population from Nanning.

was performed during the rice-growing season of 20182019. Stunned, yellowish rice plants were found around 30 days after transplanting in fields. Galls and hooked tips on the roots and pear-shaped females within the galls were observed. The objectives of this study were to investigate the distribution of RKN on rice in Guangxi province and to identify species of RKN populations collected from different geographical localities in Guangxi using both traditional morphological features and molecular techniques.

In this study, a total of 206 fields was investigated during the rice-growing season in 67 counties of Guangxi. The RKN symptoms on rice were observed in 66 fields of 26 counties, and $32.04 \%$ fields were infested with RKNs (Table 1, Fig. 1). The females were collected by dissecting galls, and the second-stage juveniles (J2s) were obtained from the fresh rice roots with galls. The males were extracted from rhizosphere soil of rice using the method described by Liu (2000). Slides of nematodes were observed using a light microscope ( $\mathrm{Z} 2$, the Carl Zeiss Axio Imager, Jena, Germany) for morphological characterizations. Measurements and pictures were taken using the ZEISS ZEN 2.6 (blue edition) software on a ZEISS Axiocam 506 microscope camera. Body length, maximum body width, dorsal pharyngeal gland orifice to stylet base, hyaline tail terminus, and stylet length were measured. The root tissues were teased apart with forceps and needles to remove adult females, and then perineal patterns were prepared and observed under a light microscope (Hunt and Handoo, 2009).

The perineal pattern of females $(n=9)$ showed dorsoventrally ovoid shape, with low to moderately high and 


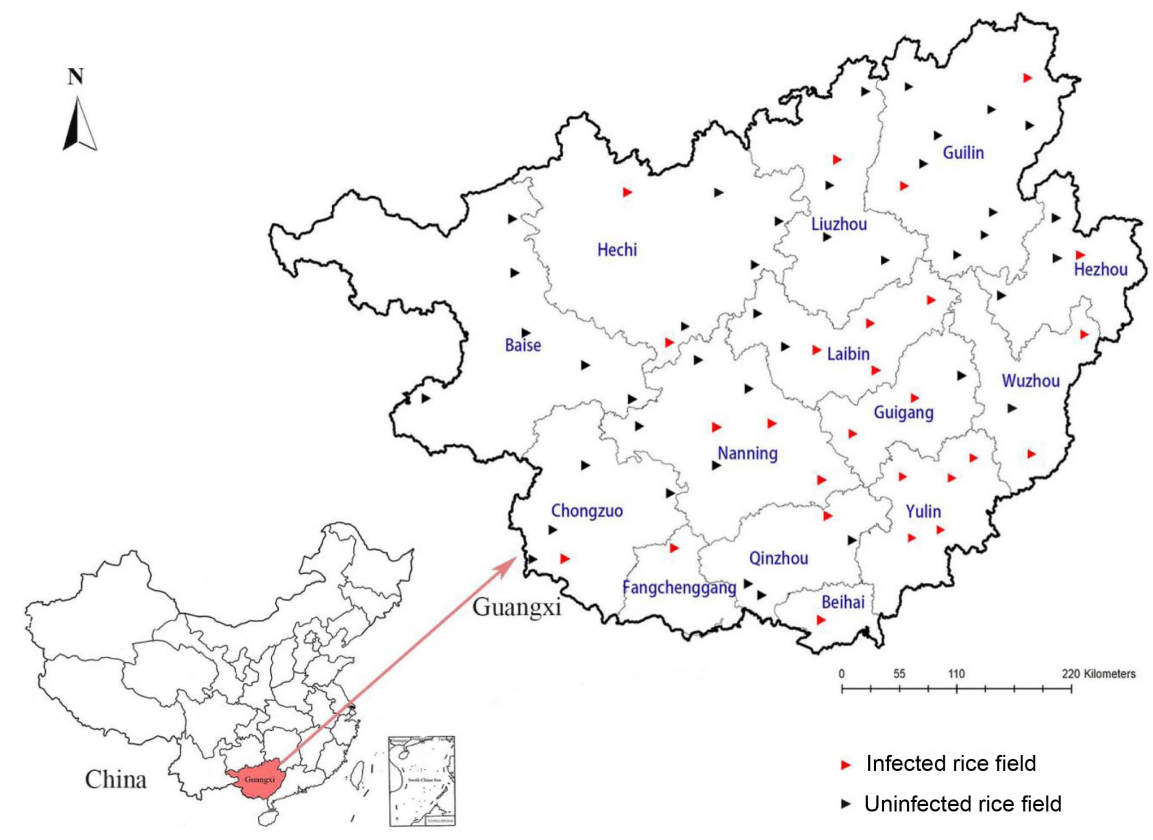

Fig. 1. Map of the locations surveyed for root-knot nematode Guangxi province, China.

round dorsal arches. Striae were smooth and continuous around the perineum, lateral lines were absent, and sometimes, a few lines converge at either end of the vulva, the character of this perineal pattern was good agreement with other description of $M$. graminicola reported, and was different from that of $M$. incognita and M. javanica with obvious lateral lines (Hunt and Handoo, 2009). Measurements (mean \pm standard error, range) of males $(n=23)$ were obtained for body length $(1,289.25 \pm 149.49 \mu \mathrm{m}$, 1,040.26-1,581.30 $\mu \mathrm{m})$, body width $(43.33 \pm 4.54 \mu \mathrm{m}$, 27.03-47.99 $\mu \mathrm{m})$, stylet length $(17.15 \pm 0.76 \mu \mathrm{m}, 15.29$ $18.41 \mu \mathrm{m})$, dorsal pharyngeal gland orifice to stylet base (3.61 $\pm 0.54 \mu \mathrm{m}, 2.53-4.46 \mu \mathrm{m})$, and spicule length (29.81 $\pm 2.68 \mu \mathrm{m}, 21.95-35.67 \mu \mathrm{m})$. Measurements of $\mathrm{J} 2(n=21)$ included body length $(470.80 \pm 26.09 \mu \mathrm{m}, 408.59-521.53$ $\mu \mathrm{m})$, body width $(17.95 \pm 1.55 \mu \mathrm{m}, 15.73-22.29 \mu \mathrm{m})$, stylet length $(12.57 \pm 0.76 \mu \mathrm{m}, 11.33-14.24 \mu \mathrm{m})$, and hyaline tail terminus $(22.31 \pm 2.54 \mu \mathrm{m}, 17.82-26.07 \mu \mathrm{m})$ (Fig. 2). The morphology and morphometric values of males were matched well with the first description of $M$. graminicola reported by Golden and Birchfield (1965) and with those of other populations in China, except for body lengths, stylet lengths, and spicule lengths of this study are shorter than those of Hunan's population (Table 2). The average body length of the J2s in our study was $470.80 \mu \mathrm{m}$, ranged from 408.59 to $521.53 \mu \mathrm{m}$, slightly longer than those of Sichuan, Zhejiang, and the first report. The J2s average stylet length of the Guangxi population is consistent with those of other Chinese populations, except for the Hunan population, which had slightly longer stylets. The hyaline tail terminus of Guangxi population was longer compared to other populations (Table 2). These small variations of morphometric are within the range of species variation of $M$. graminicola (Tian et al., 2018). As is known, the lengths of stylet, spicule, and vulva are considered as the key diagnostic parameters for the identification of M. graminicola. In previous studies, ten isolates of $M$. graminicola from Nepal, Bangladesh, USA, and India showed variations in morphometric measurements, while the internal transcribed spacer (ITS) sequences of all ten isolates were identified as M. graminicola (Pokharel et al., 2010). Similarly, the morphometric measurements of the Guangxi population also showed variation compare to different geographical populations from other provinces. It is possible that these morphometrical differences are due to geographical intraspecific variability and species variation, or phenotypic plasticity commonly exhibited by nematodes (Apolônio Silva de Oliveira et al., 2017; Pokharel et al., 2010; Salalia et al., 2017).

Ten J2s were handpicked and transferred individually to Eppendorf tubes with $19 \mu 1$ of sterilized water for the confirmation of the morphological identification. DNA was extracted using the method of Qiu et al. (2016). Each nematode was frozen in liquid nitrogen for $1 \mathrm{~min}$ and heated in $85^{\circ} \mathrm{C}$ water bath for $2 \mathrm{~min}$. The process repeated 
Table 2. Morphometrics of male and second-stage juvenile Meloidogyne graminicola populations isolated from different places ( $\mu \mathrm{m})$

\begin{tabular}{|c|c|c|c|c|c|c|}
\hline \multirow[b]{2}{*}{$\begin{array}{l}\text { Sample } \\
\text { type }\end{array}$} & \multirow[b]{2}{*}{$\begin{array}{l}\text { Morphological } \\
\text { character }\end{array}$} & \multicolumn{5}{|c|}{ Origin } \\
\hline & & $\begin{array}{l}\text { Guangxi } \\
\text { (This study) }\end{array}$ & $\begin{array}{c}\text { Hunan } \\
\text { (Song et al., 2017) }\end{array}$ & $\begin{array}{c}\text { Sichuan } \\
\text { (Xie et al., 2019) }\end{array}$ & $\begin{array}{c}\text { Zhejiang } \\
\text { (Tian et al., 2018) }\end{array}$ & $\begin{array}{l}\text { Baton Rouge, } \\
\text { Louisiana, USA } \\
\text { (Golden and } \\
\text { Birchfield, 1965) }\end{array}$ \\
\hline \multirow[t]{6}{*}{ Males } & Sample number & 23 & 20 & 10 & 17 & 20 \\
\hline & Body length & $\begin{array}{l}1,289.25 \pm 149.49 \\
(1,040.26-1,581.3)\end{array}$ & $\begin{array}{c}1,475.8 \pm 169.7 \\
(1,246.1-1,832.3)\end{array}$ & $\begin{array}{c}1,270.0 \pm 76.2 \\
(1,043.5-1,553.5)\end{array}$ & $\begin{array}{c}1,270 \pm 158.8 \\
(1,043.4-1,553.4)\end{array}$ & $\begin{array}{c}1,222 \\
(1,020-1,428)\end{array}$ \\
\hline & Body width & $\begin{array}{c}43.33 \pm 4.54 \\
(27.03-47.987)\end{array}$ & $\begin{array}{l}39.0 \pm 5.0 \\
(30.6-48.4)\end{array}$ & - & - & $\begin{array}{c}29.8 \\
(24-34.7)\end{array}$ \\
\hline & Stylet length & $\begin{array}{c}17.15 \pm 0.76 \\
(15.29-18.41)\end{array}$ & $\begin{array}{c}19.3 \pm 0.9 \\
(17.9-20.6)\end{array}$ & $\begin{array}{l}17.2 \pm 0.7 \\
(15.2-18.9)\end{array}$ & $\begin{array}{c}17.2 \pm 1.0 \\
(15.2-18.9)\end{array}$ & $\begin{array}{c}16.8 \\
(16.2-17.3)\end{array}$ \\
\hline & Spicule length & $\begin{array}{c}29.81 \pm 2.68 \\
(21.95-35.67)\end{array}$ & $\begin{array}{l}30.7 \pm 2.4 \\
(27.2-36.1)\end{array}$ & - & $\begin{array}{l}21.1 \pm 0.8 \\
(20.1-21.9)\end{array}$ & $\begin{array}{c}28.1 \\
(27.4-29.1)\end{array}$ \\
\hline & $\begin{array}{l}\text { Dorsal pharyngeal gland } \\
\text { orifice to stylet base }\end{array}$ & $\begin{array}{l}3.61 \pm 0.54 \\
(2.53-4.46)\end{array}$ & $\begin{array}{l}3.8 \pm 0.5 \\
(2.9-4.6)\end{array}$ & - & - & $\begin{array}{c}3.3 \\
(2.8-3.9)\end{array}$ \\
\hline \multirow[t]{5}{*}{ Juveniles 2} & Sample number & 21 & 20 & 20 & 20 & 20 \\
\hline & Body length & $\begin{array}{c}470.80 \pm 26.09 \\
(408.59-521.53)\end{array}$ & $\begin{array}{c}483.0 \pm 22.4 \\
(427.0-514.9)\end{array}$ & $\begin{array}{c}446.7 \pm 12.8 \\
(402.6-509.1)\end{array}$ & $\begin{array}{l}456.7 \pm 31.8 \\
(402.7-509.0)\end{array}$ & $\begin{array}{c}441 \\
(415-484)\end{array}$ \\
\hline & Body width & $\begin{array}{c}17.95 \pm 1.55 \\
(15.73-22.29)\end{array}$ & $\begin{array}{l}17.5 \pm 1.6 \\
(15.5-20.0)\end{array}$ & - & - & - \\
\hline & Stylet length & $\begin{array}{c}12.57 \pm 0.76 \\
(11.33-14.24)\end{array}$ & $\begin{array}{c}14.0 \pm 0.5 \\
(13.2-15.5)\end{array}$ & $\begin{array}{c}12.1 \pm 0.4 \\
(10.6-13.2)\end{array}$ & $\begin{array}{c}12.1 \pm 0.7 \\
(10.6-13.1)\end{array}$ & $\begin{array}{c}11.38 \\
(11.20-12.32)\end{array}$ \\
\hline & Hyaline tail terminus & $\begin{array}{c}22.31 \pm 2.54 \\
(17.82-26.07)\end{array}$ & $\begin{array}{c}20.2 \pm 2.7 \\
(15.0-25.0)\end{array}$ & $\begin{array}{c}19.5 \pm 1.0 \\
(16.2-22.7)\end{array}$ & $\begin{array}{c}19.5 \pm 1.8 \\
(16.5-22.6)\end{array}$ & - \\
\hline
\end{tabular}

Values are presented as mean \pm standard deviation (range).

at least 3 times. The homogenate was incubated at $56^{\circ} \mathrm{C}$ in a polymerase chain reaction (PCR) buffer and $100 \mu \mathrm{g} /$ $\mathrm{ml}$ proteinase $\mathrm{K}$ for $15 \mathrm{~min}$ and incubated at $95^{\circ} \mathrm{C}$ for 10 min. The ITS1-5.8S-ITS2 rDNA region was amplified with V5367(5'-TTGATTACGTCCCTGCCCTTT-3') and 26S (5'-TTTCACTCGCCGTTACTAAGG-3') (Vrain et al., 1992). The ITS region was amplified with speciesspecific primers Mg-F3 (5'-TTATCGCATCATTTTATTTG-3') and Mg-R2 (5'-CGCTTTGTTAGAAAATGACCCT-3') (Htay et al., 2016). The D2/D3 region of 28S RNA was amplified with D2A (5'-ACAAGTACCGTGAGGGAAAGTTG-3') and D3B (5'-TCGGAAGGAACCAGCTACTA-3') (De Ley et al., 1999). The PCR program of the thermal cycler consisted of the following thermal profile: $95^{\circ} \mathrm{C}$ for $5 \mathrm{~min} ; 35$ cycles of $30 \mathrm{~s}$ at $94^{\circ} \mathrm{C}$, $52^{\circ} \mathrm{C}$ for $30 \mathrm{~s}, 72^{\circ} \mathrm{C}$ for $50 \mathrm{~s}$; and a final extension cycle of $72^{\circ} \mathrm{C}$ for $10 \mathrm{~min}$. Annealing temperatures were set up at $54^{\circ} \mathrm{C}$ for primers $\mathrm{V} 5367 / 26 \mathrm{~S}, 49^{\circ} \mathrm{C}$ for primers $\mathrm{Mg}-\mathrm{F} 3 /$ $\mathrm{Mg}-\mathrm{R} 2$, and $52^{\circ} \mathrm{C}$ for primers $\mathrm{D} 2 \mathrm{~A} / \mathrm{D} 3 \mathrm{~B}$. The amplified DNA fragments were excised from $1 \%$ agarose gel and purified using the DNA Purification Kit (Thermo Fisher Scientific, Waltham, MA, USA) according to the manufacturer's instructions to purify the PCR products. The purified products were cloned into the pMD18-T vector system (TaKaRa Bio Inc., Kusatsu, Japan) and transformed into Escherichia coli strain DH5a chemically competent cells. Three representative colonies for each PCR product were selected, plasmid DNA carrying the insert was extracted and sequenced by using the pMD18-T Vector sequencing primers. Returned sequences were analyzed and edited manually using DNAMAN version 6.0. Consensus sequences obtained were compared with other nematode species available in the GenBank database through a BLASTn homology search program.

The ITS1-5.8S-ITS2 rDNA region yielded a PCR fragment of $771 \mathrm{bp}$. The sequences were deposited in GenBank as accession nos. MN0469602, MN647543, MN513027, and MN647593, had 87-100\% similarity with those of M. graminicola isolation from Fujian, China (KM111531) and Pakistan (KX757064). The length of 


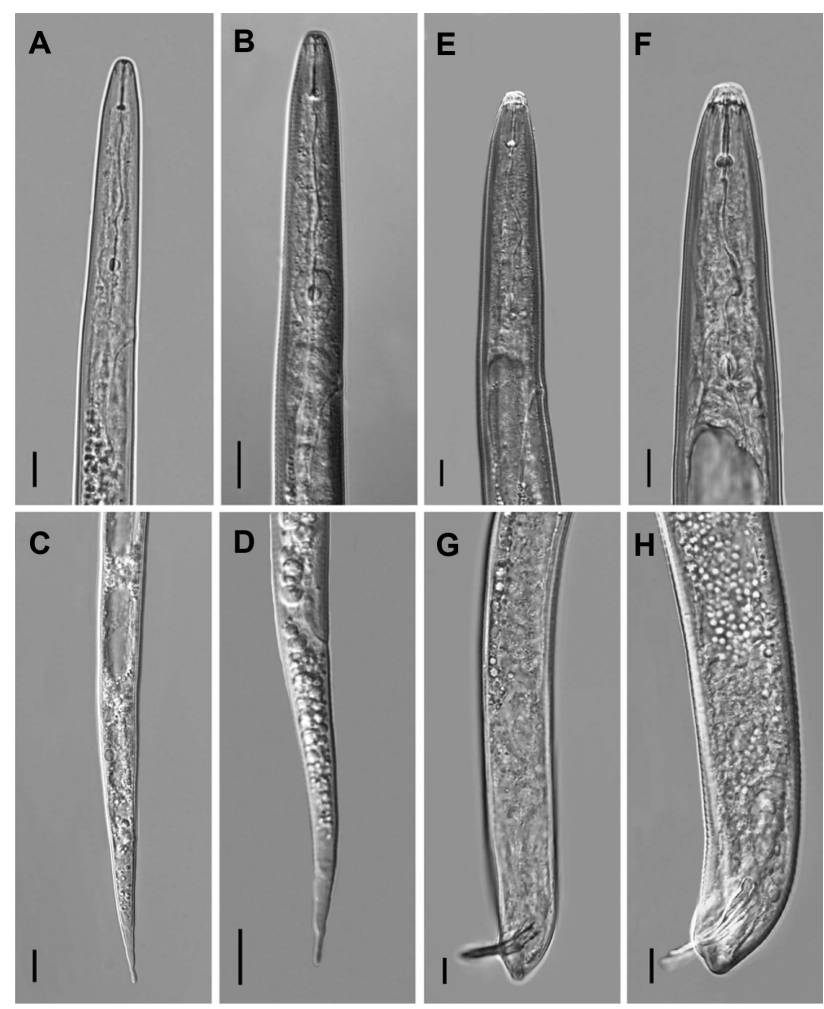

Fig. 2. Light microscope morphology. (A, B) Head region of J2s. (C, D) Posterior region of J2s. (E, F) Head region of male nematodes. $(G, H)$ Posterior region of male nematodes. Scale bars $=10 \mu \mathrm{m}(\mathrm{A}-\mathrm{H})$.

ITS region sequences of M. graminicola was 377 bp (GenBank accession nos. MN128225, MN519726, MN511736, MN521459), and had 99-100\% similarity with those of $M$. graminicola isolation from Sanya, China (MK613789), Vietnam (MG773553), and Brazil (MH703577). D2/D3 of 28S rDNA sequence of $M$. graminicola in this study was $773 \mathrm{bp}$, the region (GenBank accession nos. MN647592, MN513029, MN647589, MN647590, MN513028) was 99$100 \%$ identical to the sequences of $M$. graminicola USA isolation (AF435793 and AF435801) and Fujian, China isolation (HQ420904 and KM111529).

The phylogenetic trees based on aligned sequences of ITS1-5.8S-ITS2 rDNA, the D2/D3 of 28S rDNA and the ITS rDNA were constructed respectively by using the neighbor-joining method in MEGA5 software. M. graminicola populations formed a well-supported group within other species of Meloidogyne, and all Guangxi population (GenBank accession nos. MN049602, MN513028, MN519726, MN647543, MN513029, MN128225, MN513027, MN647592, MN511736, MN647593, MN647590, MN521459) appeared as a basal subclade in the $M$. graminicola clade, which is well-supported clade with other M. graminicola. Both morphological and molecular results confirmed that the nematode is $M$. graminicola.

Infectivity tests were confirmed in greenhouse conditions, twenty 2-week-old rice plants (cv. Teyou 09x103) were individually transplanted in pots with $1,000 \mathrm{~cm}^{3}$ autoclaved mixture of sand and field soil (sand:soil $=3: 1$ ). Each plant was inoculated $300 \pm 35 \mathrm{~J} 2 \mathrm{~s}$ hatched from RKN samples eggs. Five rice plants non-inoculated were used as control. The roots were checked at 35 days after inoculation, obvious gall formations with typical hook-shaped root tips. No symptoms were found in control roots. Root galls were opened with a dissecting needle. Females and egg mass with eggs and J2s were observed. Morphological of perineal pattern and $\mathrm{J} 2$, and molecular characteristics of RKNs isolated from inoculated roots were identical to those in the field samples.

The disease caused by M. graminicola was severe in the suburb of Nanning city and Laibin city of Guangxi, China. To the best of our knowledge, this study presents the first report of M. graminicola on rice in Guangxi, China. Guangxi is an international terminal that links Southeast Asian Nations, an important area for double-crop rice culture with about 826.6 thousand hectares. This nematode is a severe problem to rice. Due to its ability to be transmitted by soil, agricultural machinery, and particularly by contaminated seeds, the nematodes pose a considerable threat to rice production in Guangxi, China. Further study will be conducted to screen resistant rice germplasm resources against the nematode and develop effective control strategies.

\section{Acknowledgments}

This research was funded by the National Natural Science Foundation of China (31660511) and the Special Fund for Agro-Scientific Research in the Public Interest (201503114).

\section{References}

Apolônio Silva de Oliveira, D., Decraemer, W., Moens, T., dos Santos, G. A. P. and Derycke, S. 2017. Low genetic but high morphological variation over more than $1000 \mathrm{~km}$ coastline refutes omnipresence of cryptic diversity in marine nematodes. BMC Evol. Biol. 17:71.

Bridge, J., Plowright, R. A. and Peng, D. 2005. Nematode parasites of rice. In: Plant parasitic nematodes in subtropical and tropical agriculture, 2nd ed., eds. by M. Luc, R. A. Sikora and J. Bridge, pp. 87-130. CAB International, Wallingford, UK.

De Ley, P., Félix, M. A., Frisse, L. M., Nadler, S. A., Sternberg, P. 
W. and Thomas, W. K. 1999. Molecular and morphological characterisation of two reproductively isolated species with mirror-image anatomy (Nematoda: Cephalobidae). Nematology 1:591-612.

Golden, A. M. and Birchfield, W. 1965. Meloidogyne graminicola (Heteroderidae), a new species of root-knot nematode from grass. Proc. Helminthol. Soc. Wash. 32:228-231.

Htay, C., Peng, H., Huang, W., Kong, L., He, W., Holgado, R. and Peng, D. 2016. The development and molecular characterization of a rapid detection method for Rice root-knot nematode (Meloidogyne graminicola). Eur. J. Plant Pathol. 146:281291.

Hunt, D. J. and Handoo, Z. A. 2009. Taxonomy, identification and principal species. In: Root-knot nematodes, eds. by R. N. Perry, M. Moens and J. L. Starr, pp. 55-88. CAB International, Wallingford, UK.

Janati, S., Houari, A., Wifaya, A., Essarioui, A., Mimouni, A., Hormatallah, A., Sbaghi, M., Dababat, A. A. and Mokrini, F. 2018. Occurrence of the root-knot nematode species in vegetable crops in Souss region of Morocco. Plant Pathol. J. 34:308-315.

Liu, W. Z. 2000. Plant nematology. China Agriculture Press, Beijing, China. pp. 373-376. (in Chinese).

Mantelin, S., Bellafiore, S. and Kyndt, T. 2017. Meloidogyne graminicola: a major threat to rice agriculture. Mol. Plant Pathol. 18:3-15.

Negretti, R. R. R. D., Gomes, C. B., Mattos, V. S., Somavilla, L., Manica-Berto, R., Agostinetto, D., Castagnone-Sereno, P. and Carneiro, R. M. D. G. 2017. Characterisation of a Meloidogyne species complex parasitizing rice in southern Brazil. Nematology 19:403-412.

Pokharel, R. R., Abawi, G. S., Duxbury, J. M., Smat, C. D.,
Wang, X. and Brito, J. A. 2010. Variability and the recognition of two races in Meloidogyne graminicola. Australas. Plant Pathol. 39:326-333.

Qiu, Z. Q., Mo, A. S., He, Q., Wu, H. Y. and Zhou, X. B. 2016. Root-lesion nematodes on maize in Shandong, China. J. Gen. Plant Pathol. 82:224-227.

Rich, J. R., Brito, J. A., Kaur, R. and Ferrell, J. A. 2009. Weed species as hosts of Meloidogyne: a review. Nematropica 39:157-185.

Salalia, R., Walia, R. K., Somvanshi, V. S., Kumar, P. and Kumar, A. 2017. Morphological, morphometric, and molecular characterization of intraspecifc variations within Indian populations of Meloidogyne graminicola. J. Nematol. 49:254-267.

Song, Z. Q., Zhang, D. Y., Liu, Y. and Cheng, F. X. 2017. First report of Meloidogyne graminicola on rice (Oryza sativa) in Hunan province, China. Plant Dis. 101:2153.

Tian, Z.-L., Maria, M., Barsalote, E. M., Castillo, P. and Zheng, J.-W. 2018. Morphological and molecular characterization of the rice root-knot nematode, Meloidogyne graminicola, Golden and Birchfeild, 1965 occurring in Zhejiang, China. J. Integr. Agr. 17:2724-2733.

Vrain, T. C., Wakarchuk, D. A., Lévesque, A. C. and Hamilton, R. I. 1992. Intraspecific rDNA restriction fragment length polymorphism in the Xiphinema americanum group. Fundam. Appl. Nemalol. 15:563-573.

Xie, J. L., Xu, X., Yang, F., Xue, Q., Peng, Y. L. and Ji, H. L. 2019. First report of root-knot nematode, Meloidogyne graminicola, on rice in Sichuan province, Southwest China. Plant Dis. 103:2142-2142.

Zhao, H. H., Liu, W. Z., Liang, C. and Duan, Y. X. 2001. Meloidogyne graminicola, a new record species from China. Acta Phytopathol. Sin. 31:184-188 (in Chinese). 